\title{
Multivariate analysis on gross participation rate in primary school or equal by indicators of gender, residence and expenditure in indonesia year 2018, 2019 and 2020
}

\author{
Reza Syehma Bahtiar* \& Heri Retnawati \\ State University of Yogyakarta, Yogyakarta, Indonesia \\ rezasyehma.2020@student.uny.ac.id; heri_retnawati@uny.ac.id \\ *Corresponding Author: rezasyehma.2020@student.uny.ac.id | Phone Number: +6285745182452
}

\section{ARTICLE INFO \\ Received: 16-05-2021 \\ Received in revised: 20-06-2021 \\ Accepted: 26-07-2021 \\ Available online: 30-8-2021 \\ KEYWORDS \\ Multivariate prerequisite test; \\ Hierarchical cluster, \\ Hypothesis test; \\ Gross participation rate;}

\begin{abstract}
A B S T R A C T
Primary school education is an important factor for the success of the next level education. Several changes have been made to the education system in Indonesia to expand access of education in rural areas, improve the quality of education, building initiatives since 2001. In this study, the method used was Multivariate to explore the relationship between several independent variables, i.e. gender, residence and expenditure groups. Prerequisite tests performed showed that the data were normally distributed. The results of this study indicate that in the Hierarchical Cluster analysis, four clusters were found in number of gross participation rate (APK) of primary schools or equal in Indonesia year 2018, 2019 and 2020. The hypothesis test showed that gender, residence and expenditure group has no significant effect on APK of primary schools or equal students. This indicates that in year 2018, 2019 and 2020, primary schools or equal students have received education evenly in ratio of gender, residence and expenditure group.
\end{abstract}

\section{INTRODUCTION}

In a nation, education sector influences the political, economic and welfare policies (Bigagli, 2019; Etherington, 2019; Suresh \& Kumaravelu, 2017). Especially in the era of digitalization, the emphasis on education will produce good quality of human resources (Solas \& Sutton, 2018). However in developing countries, education problems pose challenges in economic growth (Adams, 2019; Bakalar, 2018; Lee, Chai \& Hong, 2019; Sukasni \& Efendy, 2017). As one of the developing countries in Southeast Asia, Indonesia is also experiencing similar problems. The challenges faced by Indonesia in education sector are not only related to the availability of access and quality of education provided, but also included equal distribution of education among students related to gender, residence and expenditure groups. According to the data from the World Bank, Indonesia has made progress in gender equality in obtaining education, which is indicated by equal distribution of literacy levels, school enrollment and employment opportunities (Yarrow \& Afkar, 2020). Data from Ministry of Education and Culture showed the number of dropouts in Indonesia for public and private primary schools for academic year 2019/2020 is 0,24\% (Kemdikb - ud, 2020). This percentage indicated progress in equal distribution of education compared to the year of 2007, where the National Commission for Child Protection reported the number of children dropping out of school reached 11.7 million students (Idrus, 2012). Primary school education is an important factor for the success of the next level of education. Several changes have been made to the education system in Indonesia to expand access to education in rural areas, improving the quality of education, building initiatives since 2001. However, the allocation of education funds in Indonesia is still relatively low, around $1.2 \%$ compared to the international benchmark of $4 \%$ to $5 \%$.

Indonesia government seeks to provide equal access to education by issuing a number of policies and initiatives through several school grants, such as the School Operational Assistance, the 'One Roof' program by combining primary and junior high schools in one building of remote areas, and Primary School Operational Assistance. These grants contribute to increasing the access and affordability of primary school education. Indonesia is close to achieving educational equity, and is making 
progress in providing quality teachers, providing classrooms and teaching materials.

Literacy performance and numeracy assessment among students in Indonesia are still low, with almost one quarter of students enrolled in Jakarta not achieving reading proficiency in Grade 2 of Primary School. The curriculum is designed to develop critical thinking, creativity and choices of contemporary knowledge for students. However, training are still needed to support teachers, both in content knowledge, thematic teaching, interactive pedagogy and group learning. Some teachers tend to return to the traditional reading method in the classroom which causes the new curriculum targets are not achieved (OECD, 2015).

In this study, the author want to analyze using Multivariate tests of Gross Participation Rate for Primary Schools or equal with indicators of gender, residence and expenditure groups in Indonesia year 2018, 2019 and 2020. This study is important to be carried out as a reference of distribution of gender, residence and expenditure groups of Primary Schools in Indonesia.

\section{METHODS}

The type of research being used is multivariate analysis which explore the relationship between several independent variables at once. This study uses 10 variables consist of one dependent variable and nine independent variables. The dependent variable in this study is the Gross Participation Rate from all Provinces of Indonesia in year 2018, 2019, and 2020. While the independent variables in this study are gender (female and male), residence (rural and city), and expenditure groups (quintiles 1 to quintiles 5 ) in Primary Schools or equal students.

The criteria for selecting the sample in this study are: (1) all provinces in Indonesia year 2018, 2019, and 2020; (2) have Gross Participation Rate of year 2018, 2019, and 2020; (3) have data of education unit number of Primary School year 2018, 2019, and 2020. The population used in this study is Gross Participation Rate of Primary students or equal in Indonesia year 2018, 2019 and 2020, while the sample indicators are gender, residence and expenditure groups in Indonesia year 2018, 2019 and 2020 (Table 1).

Table 1. Research Samples

\begin{tabular}{ccccc}
\hline No & $\begin{array}{c}\text { Independent } \\
\text { Samples }\end{array}$ & \multicolumn{3}{c}{ Gross Participation Rate } \\
\cline { 3 - 5 } & Girls & 108.29 & 107.31 & 2020 \\
\hline 1 & Boys & 108.91 & 107.61 & 106.32 \\
2 & City & 107.22 & 106.40 & 106.33 \\
3 & Rural & 110.15 & 108.71 & 107.20 \\
4 & Quintiles 1 & 110.27 & 108.82 & 107.08 \\
5 & Quintiles 2 & 108.83 & 108.40 & 106.64 \\
6 & Quintiles 3 & 108.38 & 107.28 & 106.46 \\
7 & Quintiles 4 & 107.58 & 106.30 & 105.88 \\
8 & Quintiles 5 & 107.19 & 105.55 & 104.94 \\
9 & Indonesia & 108.61 & 107.46 & 106.32 \\
10 & & & &
\end{tabular}

Resources of this study is secondary data, namely data that is not obtained directly. The data used in this study is obtained from the Gross Participation Rate of Primary Schools or equal issued by the Central Statistics Agency in website https://www.bps.go.id/ .

Gross Participation rate is the ration of the number of students at a certain level of education to the total population according to the age group. More specifically, this study uses the Primary Schools or equal Gross Participation Rate which can be calculated using the following formula:

Gross Participation $=\frac{\sum \text { Number of students Primary Schools }}{\sum \text { Number of People Aged } 7-12 \text { years }} x 100$

\section{RESULTS AND DISCUSSIONS}

Results

\section{Prerequisite Analysis}

The normality test objective is to test whether the data in the regression model contains confounding variables or the residuals have a normal distribution (Ghozali, 2011). The normality test is intended to determine whether the residuals of the regression model under study are normally distributed or not. In this study, the normality test was carried out using Kolmogorov-Smirnov test, with the basis for making decisions are as follows (CLICT, 2002): (1) If the probability value (Asymp. Sig.) < 0,05, the distribution is not normal; (2) If the probability value (Asymp. Sig.) $>0,05$, the distribution is normal.

Table 2. Normality Test - One Sample Kolmogrov - Smirnov

\begin{tabular}{|c|c|c|}
\hline \multicolumn{3}{|c|}{ One-Sample Kolmogorov-Smirnov Test } \\
\hline \multirow{2}{*}{\multicolumn{2}{|c|}{ T }} & Unstandardized Residual \\
\hline & & 3 \\
\hline \multirow[t]{2}{*}{ Normal Parameters ${ }^{\mathrm{a}, \mathrm{b}}$} & Mean & 1.03420042 \\
\hline & Std. Deviation & 2.20460000 \\
\hline \multirow{3}{*}{$\begin{array}{l}\text { Most Extreme } \\
\text { Differences }\end{array}$} & Absolute & .385 \\
\hline & Positive & .385 \\
\hline & Negative & -.282 \\
\hline \multicolumn{2}{|c|}{ Test Statistic } & .385 \\
\hline \multicolumn{2}{|c|}{ Asymp. Sig. (2-tailed) } & $.410^{c, d}$ \\
\hline
\end{tabular}

The results of statistical test One Sampel KolmogrovSmirnov showed the Sig. with value 0.410 , meaning that the value is greater than 0.05 . It can be concluded that the residual value is normally distributed or meets the requirements of the normality test.

According to Ghozali (2016), the Multicollinearity test objective is to determine whether the regression model found a correlation between independent variables assuming a linear regression model that is perfectly or imperfectly correlated. The existence of perfect Multicollinearity will result in the regression coefficient cannot be determined and the standard deviation will be 
infinite. If the Multicollinearity is imperfect, the regression coefficient even though finite, will have a large standard deviation and it means that the coefficient cannot be estimated easily (CLICT, 2002).

The detection of the presence or absence of Multicollinearity in the regression model can be seen from the tolerance value or variance inflation factor (VIF). As a basis of references can be concluded: (1) If the tolerance value is $>0.10$ and VIF value $<10$, it can be concluded that there is no Multicollinearity between the independent variables in the regression model; (2) If the tolerance value is $<0.10$ and VIF value $>10$, it can be concluded that there is Multicollinearity between the independent variables in the regression model. The result of regression model obtained showing the values and VIF for the following variables:

Table 3. Multicollinearity Test.

\begin{tabular}{|c|c|c|c|c|c|c|c|}
\hline \multirow[b]{3}{*}{ Model } & \multicolumn{7}{|c|}{ Coefficientsa } \\
\hline & \multicolumn{2}{|c|}{$\begin{array}{l}\text { Unstandardized } \\
\text { Coefficients }\end{array}$} & \multirow{2}{*}{\begin{tabular}{|} 
Standardi \\
zed \\
Coefficien \\
ts \\
Beta \\
\end{tabular}} & \multirow[b]{2}{*}{$\mathrm{t}$} & \multirow[b]{2}{*}{ Sig. } & \multicolumn{2}{|c|}{$\begin{array}{c}\text { Collinearity } \\
\text { Statistics }\end{array}$} \\
\hline & B & Std. Error & & & & Tolerance & VIF \\
\hline $\begin{array}{c}1 \text { (Consta } \\
\text { nt) }\end{array}$ & -1.019 & 1.200 & & -.849 & .552 & & \\
\hline$X$ & .112 & .001 & 1.000 & 90.390 & .007 & 1.000 & 1.000 \\
\hline
\end{tabular}

Based on Table 3 indicates the VIF value for the independent variable is not more than 10, and the tolerance value of all independent variables is also close to 1. Based on these results it can be concluded that the independent variables have no symptoms of Multicollinearity.

The concept of K-Means Method is to determine the cluster center to mark the average location for each cluster, then fix the cluster center and the degree of membership of each data point repeatedly. This iteration is based on the minimization of the objective function that describes the distance from the data point to the cluster center weighted by the degree of membership of the data point (Table 4).

Table 4.Clustering Model Final Cluster Centers Cluster

\begin{tabular}{cc|c|c} 
& 1 & 2 & 3 \\
\hline Zscore: Perempuan & .99830 & .00338 & -1.00169 \\
\hline Zscore: Laki-laki & 1.00257 & - & -.99741 \\
& & .00517 & \\
\hline Zscore: Perkotaan & .99797 & .00404 & -1.00201 \\
\hline Zscore: Pedesaan & .99200 & .01582 & -1.00782 \\
\hline Zscore: Kuintil 1 & .96836 & .06052 & -1.02889 \\
\hline Zscore: Kuintil 2 & .75264 & .38207 & -1.13471 \\
\hline Zscore: Kuintil 3 & 1.04491 & -.09688 & -.94803 \\
\hline Zscore: Kuintil 4 & 1.12176 & -.32373 & -.79803 \\
\hline Zscore: Kuintil 5 & 1.11433 & -.29505 & -.81928 \\
\hline Zscore(Y) & 1.00145 & -.00291 & -.99854 \\
\hline
\end{tabular}

Based on the analysis of the tests that have been carried out at the Final Cluster Centers by looking at the cluster grouping, table 4 is proven through the calculation of the KMeans algorithm.

\section{Cluster Analysis}

Cluster analysis is a multivariate technique that has the main goal of grouping objects based on their characteristics. Cluster analysis classifies objects so that each object that has similar properties will be grouped into the same cluster. In this study, the Gross Participation Rate for Primary Schools or equal will be grouped by Provinces in Indonesia year 2018, 2019, and 2020. The cluster analysis technique used in this test is the Hierarchy method. The test results can be seen in Figure 1.

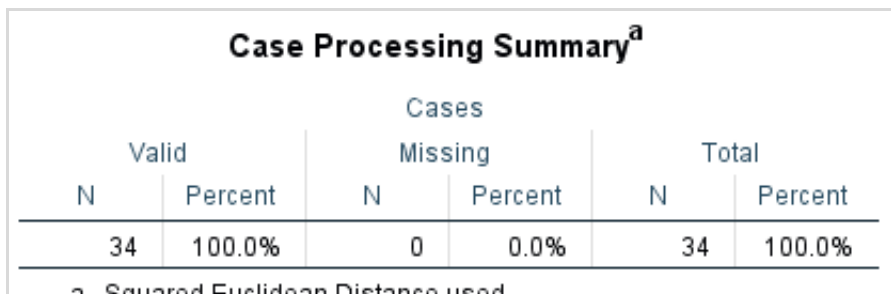

a. Squared Euclidean Distance used

Figure 1. Data Processing Summary

The Figure 1 shows the amount of data used, namely $\mathrm{N}=$ 34 provinces. The value of $100 \%$ indicates that all data is filled in and there is no empty data from the Gross Participation Rate for each provinces during 2018, 2019 and 2020. The cluster results obtained from the SPSS calculation are shown in Figure 2. 


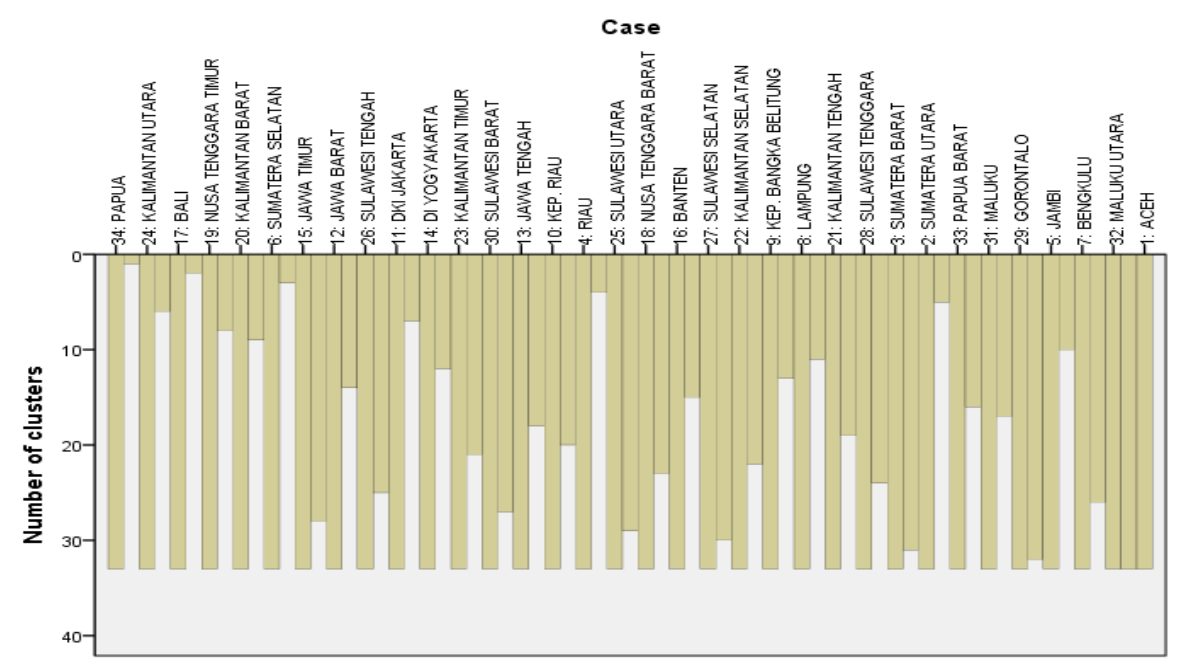

Cluster Membership
Case
4 Clusters

Figure 2.Hierarchy Clustering Method

The characteristics of each cluster can be obtained by calculating the average value for each cluster. The average value data for each Gross Participation rate of Primary Schools or equal cluster can be seen in Table 5.

Table 5. Gross Participation Rate of Primary Schools or Equal in 2018, 2019 and 2020

\begin{tabular}{|c|c|c|c|c|}
\hline \multirow{3}{*}{\multicolumn{2}{|c|}{ Provinces }} & \multirow{2}{*}{\multicolumn{2}{|c|}{$\begin{array}{c}\text { Gross Participation } \\
\text { Rate } \\
\begin{array}{c}\text { Primary Schools or } \\
\text { Equal }\end{array}\end{array}$}} & \multirow{3}{*}{$\begin{array}{c}\text { The Average of } \\
\text { Gross } \\
\text { Participation } \\
\text { Rate in 2018, } \\
2019 \text { and } 2020 \\
2018\end{array}$} \\
\hline & & & & \\
\hline & & 2020 & 2019 & \\
\hline \multicolumn{5}{|c|}{ Cluster 1} \\
\hline Aceh & 108,7 & 109,93 & 113,85 & 110,83 \\
\hline $\begin{array}{c}\text { Sumatera } \\
\text { Utara }\end{array}$ & 108,53 & 109,49 & 111,1 & 109,71 \\
\hline $\begin{array}{c}\text { Sumatera } \\
\text { Barat }\end{array}$ & 108,68 & 109,31 & 110,99 & 109,66 \\
\hline Riau & 105,89 & 106,81 & 106,92 & 106,54 \\
\hline Jambi & 109,39 & 111,11 & 111,98 & 110,83 \\
\hline Bengkulu & 109,22 & 109,98 & 113,53 & 110,91 \\
\hline Lampung & 105,93 & 107,36 & 110,11 & 107,80 \\
\hline $\begin{array}{c}\text { Kep. Bangka } \\
\text { Belitung }\end{array}$ & 107,43 & 108,44 & 111,15 & 109,01 \\
\hline Kep. Riau & 106,31 & 107,64 & 107,3 & 107,08 \\
\hline
\end{tabular}

\begin{tabular}{|c|c|c|c|c|}
\hline Dki Jakarta & 103,43 & 104,83 & 105,27 & 104,51 \\
\hline Jawa Barat & 104,72 & 105,52 & 106,24 & 105,49 \\
\hline Jawa Tengah & 106,32 & 107,74 & 108,18 & 107,41 \\
\hline DI Yogyakarta & 105,96 & 106,18 & 105,84 & 105,99 \\
\hline Jawa Timur & 104,35 & 105,56 & 106,69 & 105,53 \\
\hline Banten & 107,24 & 107,93 & 109,5 & 108,22 \\
\hline $\begin{array}{c}\text { Nusa Tenggara } \\
\text { Barat }\end{array}$ & 107,02 & 108,5 & 108,82 & 108,11 \\
\hline $\begin{array}{c}\text { Kalimantan } \\
\text { Tengah }\end{array}$ & 108,49 & 110,05 & 110,02 & 109,52 \\
\hline $\begin{array}{l}\text { Kalimantan } \\
\text { Selatan }\end{array}$ & 107,28 & 108,69 & 110,21 & 108,73 \\
\hline $\begin{array}{l}\text { Kalimantan } \\
\text { Timur }\end{array}$ & 105,75 & 106,84 & 108,02 & 106,87 \\
\hline Sulawesi Utara & 106,62 & 108,17 & 109,02 & 107,94 \\
\hline $\begin{array}{c}\text { Sulawesi } \\
\text { Tengah }\end{array}$ & 103,95 & 105,13 & 105,28 & 104,79 \\
\hline $\begin{array}{l}\text { Sulawesi } \\
\text { Selatan }\end{array}$ & 106,99 & 108,46 & 110,28 & 108,58 \\
\hline $\begin{array}{l}\text { Sulawesi } \\
\text { Tenggara }\end{array}$ & 107,97 & 109,25 & 110,81 & 109,34 \\
\hline Gorontalo & 109,48 & 110,88 & 111,95 & 110,77 \\
\hline Sulawesi Barat & 106,05 & 107,32 & 108,56 & 107,31 \\
\hline Maluku & 110,08 & 112,19 & 112,25 & 111,51 \\
\hline Maluku Utara & 108,71 & 109,73 & 113,74 & 110,73 \\
\hline
\end{tabular}




\begin{tabular}{|c|c|c|c|c|c|}
\hline Papua Barat & 110,17 & 111,24 & 110,72 & \multicolumn{2}{|c|}{110,71} \\
\hline \multicolumn{6}{|c|}{ Cluster 2} \\
\hline Sumatera $\mathrm{S}$ & $\tan$ & 111,58 & 113,3 & 114,14 & $\begin{array}{c}113 \\
01\end{array}$ \\
\hline Nusa Tengga & Timur & 113,4 & 114,95 & 116,58 & $\begin{array}{c}114 \\
98\end{array}$ \\
\hline Kalimantar & arat & 111,53 & 112,58 & 116,97 & $\begin{array}{c}113 \\
69\end{array}$ \\
\hline \multicolumn{6}{|c|}{ Cluster 3} \\
\hline Bali & & 102,87 & 103,52 & 103,02 & $\begin{array}{c}103 \\
14\end{array}$ \\
\hline Kalimantar & tara & 100,54 & 101,17 & 102,31 & $\begin{array}{c}101 \\
34\end{array}$ \\
\hline \multicolumn{6}{|c|}{ Cluster 4} \\
\hline Papu & & 91,27 & 91,94 & 94,47 & $\begin{array}{c}92,5 \\
6\end{array}$ \\
\hline
\end{tabular}

Grouping data based on the average Gross Participation Rate value in each provinces in Indonesia in 2018, 2019 and 2020 shows that Cluster 2 has the highest GPR value, with a range of 112.5 - 115.5, followed by Cluster 1 data with a range of $104.0-112.0$, then Cluster 3 with a range of 101.0 - 103.5, and the lowest GPR value is in Cluster 4 with 92.56. Furthermore, by calculating the average value of the independent variables, the distribution of the GPR indicators values can be seen Table 6 .

Table 6. GPR Value of Primary Schools or Equal to Independent Variables

\begin{tabular}{cccccccccc}
\hline \multirow{2}{*}{ GPR } & \multicolumn{9}{c}{ GPR Indicator for Primary Schools or Equal } \\
\cline { 2 - 8 } & $\mathrm{Gr}$ & $\mathrm{By}$ & $\mathrm{Ct}$ & $\mathrm{Rr}$ & $\mathrm{Q} 1$ & $\mathrm{Q} 2$ & $\mathrm{Q3}$ & $\mathrm{Q} 4$ & $\mathrm{Q} 5$ \\
\hline Average GPR Value & 107,31 & 107,62 & 106,40 & 108,69 & 108,72 & 107,96 & 107,37 & 106,59 & 105,89
\end{tabular}

(2018-2020)

Note
Gr $\quad$ : Girls
By $\quad$ : Boys
$\mathrm{Ct} \quad$ : City
$\mathrm{Rr} \quad$ : Rural
$\mathrm{Q} \quad$ : Quintiles
Based on the data in Table 3 , it can be seen the
characteristics of each independent variable which shows
the average value of the GPR indicator is $105.5-109.0$
which is in the Cluster 1 distribution range.

\section{Hypothesis Testing}

This study objective is to determine whether there is a significant difference between gender, location of residence and expenditure group on the Gross Participation Rate (GPR) in 2018, 2019 and 2020. The data in this study uses the GPR value for a period of 3 years. The data is then analyzed with the help of Microsoft Office Excel application to recap the data and Statistical Product and Service Solutions for statistical testing.

The test used in this study is the Mann Whitney difference test. The Mann Whitney test is a test used to determine the average difference between variables. The basis of reference for making this test decision is if the significance value or Asymp. Sig. (2-tailed) $<0.05$ then there is a difference in the average value of the variable. However, if the significance or Asymp. Sig. (2-tailed) $>0.05$ then there is no difference in mean. The results of the Mann Whitney test are shown in Table 7.
Table 7. Mann Whitney Test Based on Gender Indicator

\begin{tabular}{cccc}
\hline \multicolumn{4}{c}{ Test Statistics $^{\mathrm{a}}$} \\
\hline & APK 2018 & APK 2019 & APK 2020 \\
\hline Mann-Whitney U & 0.000 & 0.000 & 0.000 \\
\hline Wilcoxon W & 1.000 & 1.000 & 1.000 \\
\hline Z & -1.000 & -1.000 & -1.000 \\
\hline Asymp. Sig. (2-tailed) & 0.317 & 0.317 & 0.317 \\
\hline $\begin{array}{c}\text { Exact Sig. [2*(1-tailed } \\
\text { Sig.)] }\end{array}$ & $1.000^{\mathrm{b}}$ & $1.000^{\mathrm{b}}$ & $1.000^{\mathrm{b}}$ \\
\hline \multicolumn{3}{c}{ a. Grouping Variable: Jenis Kelamin } \\
\hline \multicolumn{3}{c}{ b. Not corrected for ties. }
\end{tabular}

Referring to the results of the Mann Whitney test in Table 7 above, the Asymp value is known Sig. (2-tailed) of GPR 2018, GPR 2019 and GPR 2020 is 0.317. Asymp Value. Sig. (2-tailed) is certainly greater than the probability of 0.05. In accordance with the basis for making the Mann Whitney test decision, it can be concluded that there is no significant difference between the gross participation rates year 2018, 2019 and 2020 when viewed by gender or in other words, both male and female, there is no difference in the Gross Participation Rate of 2018, 2019 and 2020.

Next is to find out the difference in the gross participation rate based on the location of the participant's residence. The test results can be shown in Table 8 .

Table 8.Mann Whitney Test Based on the Residence Indicator

\begin{tabular}{cccc}
\hline \multicolumn{4}{c}{ Test Statistics $^{\mathrm{a}}$} \\
\\
\hline APK 2018 & APK 2019 & APK 2020 \\
\hline Mann-Whitney U & 0.000 & 0.000 & 0.000 \\
\hline Wilcoxon W & 1.000 & 1.000 & 1.000 \\
\hline
\end{tabular}




\begin{tabular}{cccc}
\hline $\mathrm{Z}$ & -1.000 & -1.000 & -1.000 \\
\hline Asymp. Sig. (2-tailed) & 0.317 & 0.317 & 0.317 \\
\hline $\begin{array}{c}\text { Exact Sig. [2*(1-tailed } \\
\text { Sig.)] }\end{array}$ & $1.000^{\mathrm{b}}$ & $1.000^{\mathrm{b}}$ & $1.000^{\mathrm{b}}$ \\
\hline \multicolumn{3}{c}{ a. Grouping Variable: Tempat Tinggal } \\
\hline \multicolumn{3}{c}{ b. Not corrected for ties. }
\end{tabular}

Sig. (2-tailed) of GPR 2018, 2019 and 2020 based on test results is $0.317>0.05$ probability. So it is concluded that there is no significant difference between the Gross Participation Rates in 2018, 2019 and 2020 when viewed based on the location of residence, both rural and city.

Subsequent tests were conducted to compare the expenditure groups against the Gross Participation Rate. The test results can be seen in Table 9 .

Table 9. Kruskal Wallis Testing Based on Expenditure Indicator

\begin{tabular}{cccc}
\hline \multicolumn{4}{c}{ Test Statistics ${ }^{\mathrm{a}, \mathrm{b}}$} \\
& APK 2018 & APK 2019 & APK 2020 \\
\hline Chi-Square & 4.000 & 4.000 & 4.000 \\
\hline $\mathrm{df}$ & 4 & 4 & 4 \\
\hline Asymp. Sig. & 0.406 & 0.406 & 0.406 \\
\hline \multicolumn{4}{c}{ a. Kruskal Wallis Test } \\
\hline \multicolumn{4}{c}{ b. Grouping Variable: Kelompok Pengeluaran } \\
\hline
\end{tabular}

Based on the expenditure group, it indicates there is no real and significant difference between the 2018, 2019, and 2020 Gross Participation Rates. This result is showed by the Asymp value. Sig. (2-tailed) obtained is more than 0.05, namely 0.406 , or in other words the expenditure group does not provide a significant difference to the GPR year 2018, 2019 and 2020.

\section{DISCUSSIONS}

The results of the hierarchical cluster distribution obtained if sorted from the GPR values of Primary Schools or equal in Indonesia year 2018, 2019 and 2020, from the highest to the lowest will be obtained in the order: Cluster 2 (112.5 115.5), Cluster 1 (104.0 - 112.0), Cluster 3 (101.0 - 103.5), and Cluster 4 with GPR 92.56. The average value of the GPR of the independent variables shows that the distribution of the independent variables is in the range $105.5-109.0$ and is distributed in Cluster 1.

According to the Central Statistics Agency, the GPR value of Primary Schools or equal is the ratio between the number of people who are still in primary school or equal to the total population aged 7-12 years. The function of the GPR value is: (1) as an indicator of the level of population participation at a level of education; (2) as an indicator of the capacity of the education system to accommodate students from certain school age groups; (3) as a complementary indicator of the Net Participation Rate (NPR), so that it can be shown the number of people who attend school at a certain level but the age is not sufficient or exceeds the school age that should be.

The results of this study indicates that gender, residence and expenditure group have no significant effect on the Gross Participation Rate (GPR) of Primary Schools or equal. This indicates that in 2018, 2019 and 2020, Primary or equal students in Indonesia have received education evenly when compared to the ratio of gender, residence and expenditure group. This result is in line with the 1945 Constitution Article 31 Paragraph (1) which states that "Every citizen has the right to be educated" and Government Regulation Number 47 of 2008 concerning Compulsory Education. The Minister of Education and Culture also issued Regulation Number 19 of 2016 concerning the Smart Indonesia Program which supports the implementation of universal secondary education or pilot 12-year compulsory education. Article 31 Paragraph (2) of the 1945 Constitution states "Every citizen is obliged to attend basic education and the government is obliged to pay for it." So there is no difference between women or men, city or rural residence, or expenditure groups. Every child aged 7-12 years is required to attend Primary School or equal education

\section{CONCLUSIONS}

Prerequisite tests performed showed that the data were normally distributed. The results of this study indicate that in the Hierarchical Cluster analysis, the distribution of GPR for Primary School or equal in Indonesia consists of 4 clusters, in order from the highest to the lowest GPR values, namely: Cluster 2 (112.5 - 115.5), Cluster 1 (104.0 - 112.0), Cluster 3 (101.0 - 103.5), and Cluster 4 with GPR 92.56. The average value of the GPR of the independent variables shows that the distribution of the independent variables is in the range 105.5 - 109.0 and is distributed in Cluster 1 . Then when hypothesis testing is carried out on the independent variables: gender, residence and expenditure group, the results showed that there is no significant effect on the Gross Participation Rate (GPR) of Primary or equal students in Indonesia year 2018, 2019, and 2020. This indicates that in 2018, 2019 and 2020, Primary or equal students in Indonesia have received education evenly when compared to the ratio of gender, residence and expenditure group. This result is in line with the Government's Program on Compulsory Education.

\section{Acknowledgement}

The authors would like to thanks the supervisors from State University of Yogyakarta

\section{Author's Contributions}

All authors discussed the results and contributed to from the start to final manuscript. 


\section{Conflict of Interest}

The authors declare that they have no competing interests.

\section{REFERENCES}

Adams, B. (2019). The Far Reaching Impact of Transformative Curriculum. Journal of Curriculum Studies Research, 1(1), 17-32.

Bakalar, B. (2018). Book Review: Justice on both sides: Transforming education through restorative justice. American Journal of Qualitative Research, 2(2), 145-149.

Bigagli, F. (2019). School, ethnicity and nation-building in postcolonial Myanmar. Research in Educational Policy and Management, 1(1), 1-16.

BPS. (2020). Statistik Pendidikan. http://statistik.data.kemdikbud.go.id/index.php/page/sd

Center Laboratory and ICT (CLICT). (2002). Panduan Praktis Analisis SPSS untuk Manajemen (Keuangan, SDM \& Pemasaran. Universitas Negeri Malang.

Etherington, M. (2019). The Challenge with Educational Transformation. Journal of Culture and Values in Education, 2(1), 96-112.

Ghozali, Imam. (2011). Aplikasi Analisis Multivariate dengan Program SPSS. Semarang: Badan Penerbit Universitas Diponegoro.

Ghozali, Imam. (2016). Aplikasi Analisis Multivariate dengan Program IBM SPSS 23 (Edisi 8). Cetakan ke VIII. Semarang: Badan Penerbit Universitas Diponegoro.
Idrus, M. (2012). Mutu Pendidikan dan Pemerataan Pendidikan di Daerah. Psikopedagogia, 1(2).

Kemdikbud. (2020). Statistik Pendidikan. http://statistik.data.kemdikbud.go.id/index.php/page/sd

Lee, M. H., Chai, C. S., \& Hong, H. Y. (2019). STEM Education in Asia Pacific: Challenges and Development. Asia-Pacific Education Researcher.

Mendikbud. Peraturan Nomor 19 Tahun 2016 tentang Program Indonesia Pintar

OECD. (2015). Education in Indonesia: Rising to the Challenge. Paris: OECD Publishing.

Peraturan Pemerintah Nomor 47 Tahun 2008 tentang Wajib Belajar.

Solas, E., \& Sutton, F. (2018). Incorporating Digital Technology in the General Education Classroom. Research in Social Sciences and Technology, 3(1), 1-15.

Sukasni, A., \& Efendy, H. (2017). The Problematic of Education System in Indonesia and Reform Agenda. International Journal of Education, 9(3), 183.

Suresh, E. S. M., \& Kumaravelu, A. (2017). The quality of education and its challenges in developing countries. In the 2017 ASEE International Forum. Columbus: American Society for Engineering Education.

Undang-Undang Dasar 1945 Amandemen.

Yarrow, N. \& Afkar, R. (2020). Gender and Education in Indonesia: Progress with More Work to be Done. Retrieved from World Bank Blogs:

https://blogs.worldbank.org/eastasiapacific/gender-andeducation-indonesia-progress-more-work-be-done. 